\author{
Anna Szyjkowska-Piotrowska \\ - https://orcid.org/0000-0001-5478-3336 \\ Academy of Fine Arts in Warsaw \\ anna.szyjkowska-piotrowska@cybis.asp.waw.pl
}

\title{
PROPER NAME
}

\begin{abstract}
It could be said that discourse used to be understood as some kind of a "hyper-cloud" produced by many people speaking and writing within the domain of certain problems, whereas today it seems more "custom-made" and divided into smaller entities. This tendency is probably an integral part of the development of CDA and a consequence of its being well-adapted to various interdisciplinary studies, among them art practices.

And yet it seems that the blurred, non-personal quality of discourse which highlights the collective aspects of language and thinking still lingers also in the realm of artistic practices. Therefore, while in the nets of discourse, an artist and/or a work of art need to negotiate the possibility to retain the idiom of individual practice.
\end{abstract}

Keywords: discourse, CDA, art, philosophy

\section{Introduction}

The subject of the present Art Inquiry/Recherches sur les Arts: Art in the World of Discourses seems to be a very adequate tribute to the artistic and philosophical work of Grzegorz Sztabiński, editor-in-chief of the journal.

By formulating the problematics in such a broad way, the implication that $\operatorname{art}^{1}$ constitutes discourse/s can be avoided. It is not imposed and yet it is not excluded. Such a formulation raises a question concerning the relation of art

1 Art manifesting itself as oeuvres, whole bodies of work of a given artist or singular works of different artists. 
and discourse/s. It encourages us to ask whether oeuvre or works of art produce discourse or are forms of discourse.

I believe that this relation - between art and discourse - was crucial for Grzegorz Sztabiński, as it made the integrity of his life work possible. Both a practitioner of art and its theoretician, Professor Sztabiński was exploring interconnections between philosophy and art. His interest in changes which took place between 20th-century avant-gardes and contemporary art, in relation to the ideas tackled, was an interest of a philosopher who does not sit aside but rather forms community in practice with artists. Or, the other way round, as Stefan Morawski observed, "Sztabiński is not a doctrinaire who converts philosophical abstractions into iconic signs, but a philosophizing artist" 2 . However seized, the main idea is that both forms of exploring existence - philosophy and art - were complementary and present in his work. It was a choice that I have respected. Seeing art as a form of communication and perceiving it as an intellectual endeavor was an unsaid but integral part of our theoretical connection. Ewa Wojtyniak-Dębińska even goes as far to say that: “[...] the sense that intellectual qualities are superior to visual ones determined the general direction of his artistic experiment" 3 . I am not convinced about prioritizing the intellectual but I fully agree with the statement that follows: "[...] the artist avoided dematerialization of the visual work, which is a characteristic feature of conceptual art. The reason for this was Sztabiński's fascination with the presence of the ideal and notional in the material and the sensual"4. Apart from meeting Grzegorz Sztabiński in Łódź many years ago, this is where and how I met him.

Discursivity of art becomes the conceptual foundation for further investigation within an approach that explores the presence of the notional within the sensual. In other words: the conviction that the notional is present in the sensual is a starting point to perceive discourse as being inherent to a given work of art.

Not every artist is in favor of seeing art as a form of discourse. Art can also be seen as an escape from intellectualization or language. And yet, it is hardly possible for works of art to fully escape the nets of discourse. Even if an artist does not intend to implement language into his works, this may later be done by art critics or curators. Nevertheless, those two forms of the presence of discourse should definitely be differentiated. It is a different thing for works of art to be active agents producing discourse as an emanation of their sensuality and materiality, and another for them to be later veiled in discourse in ways that can actually block their agency.

2 Ewa Wojtyniak-Dębińska, “Grzegorz Sztabiński” in: Proper names in the art of Łódź ed. Grzegorz Sztabiński, Paulina Sztabińska, the Strzemiński Academy of Fine Arts in Łódź, Łódź 2008, p. 167.

3

Ibid.

4 Ibid. 
Therefore, discursive practices concerning art should at least be divided into two groups:

a) Discursivity inherent in the work of art (conceptual works of art, works using language)

b) Discursivity as discursive practices in forms of discussions about art, its meanings and functions, various interpretations of works of art.

Intrinsic discursivity in art is then differentiated from discursive curatorial practices. Such a division, however, paradoxically becomes blurred by the socalled discursive turn itself.

In Curatorial Dictionary, an initiative undertaken by Hungarian curators to clarify curatorial discourse, we can read that:

“(...) discursivity in art and curatorial practices has gained momentum when dematerialized mediums (i.e. lectures, symposia, discussions, talks, workshops, etc.) were initiated as the projects themselves. That is, discursive events that were in the 1970s and 1980s regarded as supplements to the exhibition, have taken center stage within the exhibition space ( exhibition display $\sim$ curatorial). This is also referred to as the discursive turn in contemporary art. Discursive practices within contemporary art are built partly on conceptual art traditions, reflecting on the meaning(s) of art, the function and social responsibility of the museums, or the social position and status of the artist ( interpretation $\sim$ performativity). Discursive practices have not only changed the form, content, and presentation mode of artworks ( exhibition display), but also the function of institutions, their exhibition policy, and even the role of the actors within them ( performativity collaboration). At the same time, this discursive shift also indicates the perpetual critical assessment of these very changes"5.

In confronting the described situation, it becomes hardly possible to sharply differentiate between "curatorial supplements to the exhibition" and the exhibition itself. The former is no longer just a supplement. The shift has changed the forms of both artworks and ways of displaying them. Central to the whole change was, of course, conceptual art for which the relationship of the notional and the sensual was the question for negotiations:

"A discursive model of praxis has developed within the critical art context over the last twenty years. It is the offspring of critical theory and improvised, self-organized structures. It is the basis of art that involves the dissemination of information. It plays with social models and presents speculative constructs

5 http://tranzit.org/curatorialdictionary/index.php/dictionary/discursivity/ 
both within and beyond traditional gallery spaces. It is indebted to conceptual art's reframing of relationships, and it requires decentered and revised histories in order to evolve" 6 .

In both quoted fragments, it is clearly pointed out that discursivity as a framework of the artworld introduces constant critical underpinning, and in a way makes artworks function at the same time on subject level and meta-level, as if they were already commentaries to themselves. Art as a form of intellectual engagement and as a way of raising self-awareness is definitely the one that found itself in the nets of discourse/s.

\section{Notes on Discourse Theory}

I allow myself to write some parts of the article in a rather personal tone. Therefore, I will abandon the allegedly intersubjective perspective for a manifestly subjective one, to be able to draw some conclusions from my early experience as an academic.

In the years 2000-2008, when I simultaneously studied applied linguistics and philosophy, the term discourse was being constantly used by lecturers of both departments. One can say that it was a hip term in academic circles. Yet, there was something really intangible about the word discourse that even today makes me open my eyes wider when I see it written in plural, as if it was some form of sacrilege to further divide it into types and subtypes. It must have had an air of an idea with a capital letter. I even remember one of the seminars at the Institute of Philosophy of the University of Warsaw during which we were supposed to enumerate the features of discourse. One of the students raised his hand and said that discourse was discursive, which made most people laugh, but not the professor who conducted the seminar. She nodded and confirmed. I present this anecdote to portray the rather ephemeral allure of the term at the beginning of the 2000s.

It could be said that discourse used to be understood as some kind of "hyper-cloud" produced by many people speaking and writing within the domain of certain problems, whereas today it seems more "custom-made" and divided into smaller entities. This tendency is probably an integral part of the development of CDA and a consequence of its being well-adapted to various interdisciplinary studies, among them art practices. And yet it seems that the blurred, non-personal quality of discourse which highlights the collective aspects of

6 Liam Gillick, Maybe it would be better if we worked in groups of three. Part 1 of 2: The Discursive. e-flux Journal \#2 - January 2009, https://www.e-flux.com/journal/02/68497/maybe-it-wouldbe-better-if-we-worked-in-groups-of-three-part-1-of-2-the-discursive/ (accessed 17.08.2021). 
language and thinking still lingers also in the realm of artistic practices: "The discursive is a practice that offers one the opportunity to be a relatively unexamined, free agent within a collective project. While the discursive appears to be an open generator of positions, it actually functions best when it allows one to "hide within the collective.?"

CDA - Critical Discourse Analysis - was meant to fuel the development of different interdisciplinary studies from its very beginning. Linguistics is the very domain which gave rise to the term discourse. We can read about it in the "Introduction", co-written by Anna Duszak and Norman Fairclough, to Krytyczna analiza dyskursu. Interdyscypinarne podejście do komunikacji społecznej8 (Critical discourse analysis. Interdisciplinary approach to social communication). In this publication from 2008, Anna Duszak - one of the stars and founders of CDA - draws attention to the fact that although CDA was born within linguistics, it has been adopted by many disciplines to study their "languages" and the ways in which they describe their realities. She adds that in the scope of 25 years, CDA has conquered a large and diverse terrain of interdisciplinary studies. Thus, she claims, it becomes a field of study on its own.

Reminiscing the linguistic beginnings of CDA, it seems easy to notice that it started off as an especially constructive tool for the analysis of political language and thus found its way into sociology, political studies or international relations studies. The leap from analysis of politicians' speeches, which was useful for political sciences, to discursivity of art, does not seem to be a leap anymore if we consider the social engagement of art and its potential to shape approaches and perspectives: "The art centers, museums and galleries have usually simply been the vessels within which this activity is housed. Occasionally however, the places where art happens have also been the creative engines for a rethinking of the categories of visual art and the role of artists; of how visual culture can alter personal consciousness, and even change the world"'.

As for the CDA of political leaders' utterances, there were, for example, many analyses of George W. Bush Jr speeches performed by numerous linguists, which showed how certain terms like war on terror where adopted to obtain political goals. Duszak underlines the importance of CDA in tracing and signaling racist speech. Her claim could be easily supported by the abstract to an article by Robert K. Beshara that was published in Journal of Language and Discrimination:

7 Liam Gillick, ibid.

8 Anna Duszak, Norman Fairclough, Krytyczna analiza dyskursu. Interdyscyplinarne podejście do komunikacji spotecznej, Cracow, Universitas 2008, pp. 7-29.

9 Charles Esche, What's the Point of Art Centers Anyway? - Possibility, Art and Democratic Deviance, 4. 2004 https://transversal.at/transversal/0504/esche/en (accessed 17.08.2021) 
"In this article, I dissect an excerpt from George W. Bush's address to a joint session of Congress and the American people wherein the former President of the United States (POTUS) uttered the (catch)phrase the 'war on terror' (WOT). [...] My aim here is to deconstruct/recode the WOT discourse in the hope of opening up possibilities for alternative, and more constructive, counter-discourses on the social problem of 'terrorism' that afford multiple subject positions beyond the (counter)terrorism binary.[...] This analysis is particularly relevant in the context of the current political climate in the United States, where the WOT rhetoric continues to normalize the logic of Islamophobia" 10 .

This kind of analysis was continued with publications comparing, for example, speeches of Bush and Obama, as in: Language at War. A Critical Discourse Analysis by Speeches of Bush and Obama on War and Terrorism by Martin Lausten ${ }^{11}$.

As it can be deduced, the strength of discourse analysis lay in the fact that it took large context into consideration and used actual excerpts of speeches touching upon the real problems on the borders of language and reality. Duszak poses a crucial question: why do we say discourse rather than language? And she replies that it was a sort of response to discussions on language that would use examples which were not realistic, but rather abstract and invented, whereas discourse is supposed to deal with the authentic linguistic expression. Duszak saw far back and far forward into discourse studies, she admitted that the change from language into discourse was triggered by Michel Foucault $(1971,1972)$ and was able to notice that it was an important reply to the racist problems of the contemporary world.

She believed it was one of its main advantages. In the aforementioned "Introduction", my former lecturer argues that a lot of human sciences studies ignore the connection between the semantic and the material. Duszak further suggests that we could adopt a broad definition of discourse as semiosis - producing meanings through the richness of semiotic means that encompass not only verbal language, but also "visual language" (including body language). One can add: this is where art comes into play. This shift is far from obvious. Intellectual approach to art probably makes it easier to notice its discursive emanations. Seeing art as an interplay of meanings is not everyone's adventure.

10 Robert K. Beshara https://journal.equinoxpub.com/JLD/article/view/333 (accessed 14.08.2021)

11 Martin Lausten, Language at War. A Critical Discourse Analysis by Speeches of Bush and Obama on War and Terrorism, Grin 2016. 


\section{Proper Names in Human Sciences and Art}

It has been one of the observations that have informed my "growing up" as a theoretician that there is a lot of hypocrisy in the seemingly neutral tone of academic writing in the human sciences. Knowing more and more academics and their theoretical or emotional leanings, it was a rather bizarre experience to read some of their texts where they would reach conclusions which were in fact the reverse: a starting point, an emotional setup for an analysis, or a certain intellectual bias that they could freely share in a conversation, but would painstakingly arrive at in an article.

Needless to say, the ways we use language are multiple. Language does, of course, convey information but it is also a tool for shaping our relationships with others and conveying a certain image of ourselves. It could therefore be stated that apart from, for example, an informative or phatic function, an identity-manifesting function should also be differentiated and, as part of it - linguistic camouflage.

My approach to the term discourse is ambivalent, since it partly enables such practices of camouflaged emotionality that pass for scientific neutrality. Discourse can be understood as person-neutral, it transgresses us as something larger than just a set of individual's statements. Therefore, as an entity that trespasses a human being, it seems vague, out of reach and out of control. Understood in this way, the term discourse makes the diffusion of responsibility possible. When it seems that innumerable people are involved in making discourse, no one can really be blamed or feels responsible for the way it is - the way discourse is - be it scientific, political or any other.

The problem with the term discourse already starts with our relation to language. The question at the core of it is: is language a person's tool? In other words: can one shape/determine language? Or is it rather a structure that determines us (as in: we are the tools of language and not the reverse)?

The most vibrant moment for such a question, in the sense of the "ripples on the pond" effect, could be ascribed to Ferdinand de Saussure. As the socalled father of structuralism, he was responsible for lessening the belief in the role of subjectivity. Structuralism had an immense influence on the human sciences: philosophy, history, psychology, etc. By focusing on whole structures and thus contexts, and not just parts of phenomena, structuralism made way for a synthetic, rather than an analytical approach. Nevertheless, the focus was not on an individual, existential or psychological entity as a human being, but rather on the structural model of a given hyper-entity such as language. The shifting of attention had immense consequences in different domains.

One of those might be that some discourses of the human sciences still make us forget that behind discourse there is a person, a personality that makes 
a certain way of seeing the world emerge because of some private and personal experience, and of some inborn and/or acquired features.

This forgetfulness is also fueled by the very theoretical basis of what discourse is. It is important to note that some of the convictions accompanying the linguistic turn and ideas concerning linguistic determinism have been diluted with the passage of time. For instance, Sapir-Whorf theory, which in its radical version stipulates that the worldview in different cultures is determined through language, has already been abandoned by the majority of linguists. The trend seems to have reversed with such influential academics (in the field of philosophy) as Rosi Braidotti, trying to engage others in making mappings of their localities. Braidotti underlines the importance of embodiment, of maps which indicate our bodily, social and geographical locality. She strongly supports stating one's mapping in an academic article.

The actual term discourse has special qualities that quite clearly differentiate it from terms like style or language. Those qualities are to be observed even in the technical aspects of its linguistic use: although it is possible to make the plural form of it (discourses, as in the call for papers of this very magazine), it also functions like uncountable nouns (such as water or money). The lack of an article, or rather the use of zero article, shows that it is used as an abstract term. In today's terms, discourse still appears to be something like Timothy Morton's hyperobject, even though the plural form and individual stamps of artistic expression within discursivity of art can give it a more subjective or personal aspect: "The discursive is the key strategy employed by the most dynamic contemporary artists, whether they are providing a contribution to a larger model of exchange or using discursive strategies as a structural tool within their own work" 12 .

The way Liam Gillick defines the discursive in art is twofold - technical and "contextual": "The use of the word discursive includes the following considerations: first (a technical definition), the movement between subjects without or beyond order; second, a set of discussions marked by their adherence to one or more notions of analytical reason. At no point does my use of the word really imply coherence with notions of "discursive democracy" as posited by Habermas and others, yet within the cultural terrain it does have some connection to the idea of melding public deliberation while retaining the notion of individual practice within the "group."13"

This passage from Gillick's article pinpoints some of the intuitions that I have presented thus far, for the most important stake for art, when negotiating

12 Liam Gillick, ibidem.

13 Ibid. 
its place in the nets of discourse/s, is the possibility for the artist and for the work of art to retain the idiom of individual practice.

And this is where I can see the danger of the hyper-cloud that discourse is, despite its important role in binding socially or politically engaged discussions that makes people become a group of reflecting individuals.

In the publication Imiona własne sztuki tódzkiej/ Proper names in the art of Łódź, co-edited by Grzegorz Sztabiński and Paulina Sztabińska in 2008 ${ }^{14}$, Sztabiński declared in the "Introduction" that the criteria for selecting the artists described in the publication were that their work had a particular character, specificity of conduct in the chosen discipline. Thus, the publication is about people who marked their way functioning separately, á part - but, as I understand it, in a good way that grants personal idiom. The painter-philosopher recalled the words of Levinas which affirmed that he was interested in "the names of persons whose saying signifies a face" 15 .

To give a proper name to what you see is to single something or somebody out and see them as unique. This is where the collective aspect of discourse in art has to be negotiated to leave space for the individual face to appear.

\section{BIBLIOGRAPHY:}

Robert K. Beshara https://journal.equinoxpub.com/JLD/article/view/333 (accessed 14.08.2021)

Anna Duszak, Norman Fairclough, Krytyczna analiza dyskursu. Interdyscyplinarne podejście do komunikacji społecznej, Cracow, Universitas 2008.

Charles Esche, What's the Point of Art Centers Anyway? - Possibility, Art and Democratic Deviance, 4. $2004 \mathrm{https}: / /$ transversal.at/transversal/0504/esche/en 17.08.2021

Liam Gillick, Maybe it would be better if we worked in groups of three. Part 1 of 2: The Discursive. e-flux Journal \#2 January 2009, https://www.e-flux.com/journal/02/68497/maybe-it-would-bebetter-if-we-worked-in-groups-of-three-part-1-of-2-the-discursive/ (accessed 17.08.2021)

Martin Lausten, Language at War. A Critical Discourse Analysis by Speeches of Bush and Obama on War and Terrorism, Grin 2016.

Grzegorz Sztabiński, Paulina Sztabińska (ed.), Proper names in the art of Łódź, the Strzemiński Academy of Fine Arts in Łódź, Łódź 2008

http://tranzit.org/curatorialdictionary/index.php/dictionary/discursivity/

14 Grzegorz Sztabiński “Introduction” in: Proper names in the art of Łódź ed. Grzegorz Sztabiński, Paulina Sztabińska, the Strzemiński Academy of Fine Arts in Łódź, Łódź 2008, p. 7.

15 E. Levinas, Proper Names (translated by Michael B. Smith). Stanford Univeristy Press 1996, p. 4. 


\section{IMIĘ WŁASNE (streszczenie)}

Można powiedzieć, że rozumienie dyskursu kilkanaście lat temu przypominało swego rodzaju „hiper-chmurę” wytwarzaną przez wiele mówiących i piszących osób, podczas gdy dziś wydaje się on znacznie bardziej „skrojony na miarę” i podzielony na coraz mniejsze części. Tendencja ta jest prawdopodobnie integralną częścią rozwoju KAD i konsekwencją jego adaptacji do różnych badań interdyscyplinarnych, w tym praktyk artystycznych.

Jednak wydaje się, że „hiper-zamglona” jakość dyskursu, który podkreśla kolektywne aspekty języka i kolektywne aspekty myślenia, utrzymała się także w sferze praktyk artystycznych. To, co należy negocjować w sieci dyskursu to możliwość zachowania przez artystę i dzieło sztuki idiomu indywidualnej praktyki.

Słowa kluczowe: dyskurs, KAD, sztuka, filozofia

Anna Szyjkowska-Piotrowska - a philosopher of culture and a linguist. She holds MA degrees in Philosophy and Applied Linguistics from the University of Warsaw, where she also acquired her PhD degree in Philosophy. She lectures at the Academy of Fine Arts in Warsaw and at the Frederic Chopin University of Music. Author of the books: Po-twarz. Przekraczanie widzalności w sztuce i filozofii (After-face. Transgressing visuality in art and philosophy, 2015, słowo obraz/terytoria) and Dyrygujac falom. Myślenie w wizualno-muzycznych awangardach (Conducting the waves. Thinking in visual and musical avant-gardes, 2019, słowo obraz/terytoria). 